\title{
Clinical significance of the abnormal Doppler spectrum of renal blood flow in patients with long-term transplant dysfunction
}

\author{
V. V. Yakymenko \\ State Institution “Zaporizhzhia Medical Academy of Post-Graduate Education Ministry of Health of Ukraine”
}

Relevance. One of the main causes of graft loss in a recipient after kidney transplantation is acute rejection.

The purpose of the work - to study the Doppler ultrasound measurements of renal transplant blood flow in patients with efficient depuration function and renal graft dysfunction in the late postoperative period following KT.

Materials and methods. As an initial step, an ultrasound examination of renal transplants was performed in 26 patients with creatinine levels within the normative values (group 1) during the period 2014-2015. The second study was based on the ultrasound examination results of the renal transplants in 26 patients with creatinine levels exceeding the standard values (group 2) during the period 2015-2016.

Results. The first group of recipients included 15 male (57.7\%) and 11 (42.3\%) female (the mean age was $31.40 \pm 1.67$ years). A living related kidney transplantation (LRKT) was performed in $61.54 \%$ of patients, in $38.46 \%$ - a cadaveric kidney transplantation (CKT). In all the patients, plasma creatinine level was within normative values or not exceeding them more than $25 \%$, on average, ranging from 94 to $130 \mu \mathrm{mol} / \mathrm{L}$ and its mean value was $114.5 \pm 3.85 \mu \mathrm{mol} / \mathrm{L}$. The second group of recipients consisted of 14 $(53,84 \%)$ male and $12(46,16 \%)$ female (the mean age was $38.99 \pm 2.32$ years). LRKT was performed in 6 patients, and CKT in 20 patients. In all the patients plasma creatinine level was above the normal range, on average, ranging from 155 to $629 \mu \mathrm{mol} / \mathrm{L}$ and its mean value was $259.46 \pm 35,33 \mu \mathrm{mol} / \mathrm{L}$.

Conclusions. The obtained data reliably indicate that if TAMX of interlobar arteries less than $15 \mathrm{~cm} / \mathrm{s}$, the probability to reveal the clinical signs of renal allograft dysfunction is more than $90 \%$, regardless of the renal segment evaluation in recipients in the long-term period after organ transplantation.

\section{Киінічна значущість порушень доплерівського спектра ренального кровотоку в пацієнтів із дисфункцією трансплантата у віддалені терміни після операції}

\section{В. В. Якименко}

Одна з головних причин, що викликає загибель функціонуючої тканини нирки в реципієнта після трансплантації, - гостре відторгнення.

Мета роботи - вивчити ультразвукові характеристики, доплерографічні показники кровотоку по судинах трансплантованої нирки (ТН) у пацієнтів зі збереженою депураційною функцією та дисфункцією ниркового трансплантата у віддалені терміни після ТН.

Матеріали та методи. У період 2014-2015 рр. виконали ультразвукове дослідження (УЗД) ниркових трансплантатів 26 пацієнтам із рівнями креатиніну в межах нормативних значень (група 1). Друге дослідження базується на результатах УзД ниркових трансплантатів у 26 пацієнтів із рівнями креатиніну, що перевищують нормативні значення (група 2), у період 2015-2016 рр.

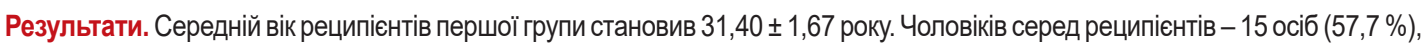
жінок - 11 (42,3 \%). Проведена споріднена ТН (CTH) у 61,54 \% пацієнтів, у 38,46 \% - трупна ТН (TTH). У всіх пацієнтів рівень креатиніну плазми відповідав нормативним значенням або перевищував їх не більше ніж на $25 \%$, коливаючись у середньому від 94 до 130 мкмоль/л, становлячи в середньому 114,50 \3,85 мкмоль/л. Середній вік реципієнтів другої групи становив 38,99 $\pm 2,32(34,35-43,62)$ року. Чоловіків серед реципієнтів - 14 осіб $(53,84 \%)$, жінок - $12(46,16 \%)$. Здійснена СТН у 6 пацієнтів, у 20 - ТТН. У всіх пацієнтів рівень креатиніну плазми був вищим за нормальні значення, коливаючись у середньому від 155 до 629 мкмоль/л, становлячи в середньому 259,46 \pm 35,33 мкмоль/л. Групи зіставні за основними клініко-демографічними параметрами.

Висновки. Дані вірогідно показують, що при ТАМХ інтерлобарних артерій менше ніж 15 см/с вірогідність виявлення клінічних ознак формування порушення функціонального статусу реального алогенного трансплантата (незалежно від оцінки сегмента нирки) становить понад 90 \% у реципієнтів у віддаленому періоді після хірургічного втручання з приводу пересадки органа.

\section{Клиническая значимость нарушений допплеровского спектра ренального кровотока у пациентов с Аисфункцией трансплантата в отдаленные сроки после операции}

\section{В. В. Якименко}

Одной из главных причин, которая вызывает гибель функционирующей ткани почки у реципиента после трансплантации, является острое отторжение.

Цель работы - изучить ультразвуковые характеристики и допплерографические показатели кровотока по сосудам трансплантированной почки (ТП) у пациентов с сохраненной и нарушенной депурационной функцией и дисфункцией почечного трансплантата в отдаленные сроки после ТП.
Key words: disease resistance, delayed graft function, kidney transplantation.

\section{Zaporozhye} medical journa 2019; 21 (2), 229-233 Dol: 10.14739/2310-1210 2019.2.161501

E-mail: diagnostica@mail.ua

Ключові слова: індекс резистентності, пізня Аисфункція ниркового трансплантату, нирковий трансплантат.

Запорізький медичний журнак. - 2019. T. 21, № 2(113). C. 229-233

Ключевые слова: инАекс резистентности, поздняя Аисфункция трансплантата, почечный трансплантат. 
Запорожский медицинский журнал. - 2019. -

T. 21, № 2(113), C. 229-233

Материалы и методы. За период 2014-2015 гг. выполнено ультразвуковое исследование (УЗИ) почечных трансплантатов у 26 пациентов с уровнями креатинина в пределах нормативных значений (группа 1). Второе исследование основано на результатах УЗИ почечных трансплантатов у 26 пациентов с уровнями креатинина, превышающими нормативные значения (группа 2) за период 2015-2016 гг.

Результаты. Средний возраст реципиентов первой группы составил 31,40 1,67 года. Мужчин среди реципиентов было 15 человек (57,7\%), женщин - 11 (42,3\%). Проведена родственная ТП (РТП) у 61,54 \% пациентов, у 38,46 \% - трупная ТП (ТTП). У всех пациентов уровень креатинина плазмы соответствовал нормативным значениям или превышал их не более чем на 25 \%, колеблясь в среднем от 94 до 130 мкмоль/л и составляя в среднем 114,50 \3,85 мкмоль/л.

Средний возраст реципиентов второй группы составил $38,99 \pm 2,32(34,35-43,62)$ года. Мужчин среди реципиентов было 14 человек (53,84 \%), женщин - 12 (46,16\%). Проведена РТП у 6 пациентов, у 20 - ТТП. У всех пациентов уровень креатинина плазмы был выше нормальных значений, колеблясь в среднем от 155 до 629 мкмоль/л, составляя в среднем 259,46 × 35,33 мкмоль/л. Группы были сопоставимы по основным клинико-демографическим параметрам.

Выводы. Данные достоверно свидетельствуют, что при ТАМХ интерлобарных артерий менее чем 15 см/с вероятность выявления клинических признаков формирования нарушения функционального статуса ренального аллогенного трансплантата, независимо от оценки сегмента почки, составляет более 90 \% у реципиентов в отдаленном периоде после хирургического вмешательства по поводу пересадки органа.

\section{Relevance}

In comparison with transplantation of other organs, such line as kidney transplantation (KT) has a history stretching back more than half a century. For this period, tremendous experience concerning surgical techniques modernization, organ preservation, improvement and optimization of immunosuppression protocols and postoperative management of patients has been accumulated and current survival rates of recipients and renal grafts have been achieved. On the contrary, the advances in KT have led to the fact that a waiting lists for the operation are steadily increasing around the world [1].

In addition to low indicators of quality of life, dialysis patients have much shorter life expectancies. Thus, patients receiving hemodialysis at the age of $40-59$ years, live on average 11 years less compared to those who underwent KT. For patients whose age group is $20-39$ years, this difference already reaches 17 years [2].

KT today is the method of choice in the treatment of patients with end-stage chronic renal failure, which can significantly improve the quality of life, contributes to a more complete social rehabilitation in this category of patients. One of the main causes of graft loss in a recipient after kidney transplantation is acute rejection. The number and severity of acute rejection cases directly correlate with loss of active nephrons and the duration of graft survival [3].

It is known that the half-life of cadaveric grafts, according to different authors, varies between 8-10 and 10-14 years, depending on the degree of compatibility and quality of organs. For kidneys obtained from living related donors, this figure is 17 years with compatibility beyond the haplotype and exceeds 30 years in main histocompatibility complex antigen-identical donor and recipient [4].

Rejection is defined as general inflammatory process of the graft, caused by a specific immune response of the recipient to the donor's transplant antigens [5]. Almost all mechanisms of cellular and humoral responses are involved in the interaction between the recipient's immune system and the antigens of the donor kidney transplant. The interaction between the antigen-specific T-cell receptor and allogeneic HLA antigens is the central event of this reaction. The main manifestation of the immunological conflict is the loss of excretory function of the donor organ or the lack of regeneration [6].
Diagnosis of acute rejection is based on clinical and instrumental studies, laboratory and immunological parameters. At the same time, punch biopsy remains the "gold standard" for assessing the pathological states in transplant nephrology. Although it is known that punch biopsy can lead to a number of complications such as hematoma, renal infarction, urinoma, etc. [7].

Ultrasound examination is often the primary diagnostic method, which is characterized by non-invasiveness, relative cheapness, imaging at patient's bed-side, there is no need for intravenous contrast, and it allows rapid and accurate detecting a number of common complications [8].

\section{The purpose of the work}

To study the Doppler ultrasound measurements of renal transplant blood flow in patients with efficient depuration function and renal graft dysfunction in the late postoperative period following $\mathrm{KT}$.

\section{Materials and methods}

An ultrasound examination of renal transplants was performed in 26 patients with creatinine levels within the normative values (group 1) during the period 2014-2015. This group of recipients included 15 male $(57.7 \%)$ and 11 $(42.3 \%)$ female, mean age was $31.40 \pm 1.67$ years. Aliving related kidney transplantation (LRKT) was performed in $61.54 \%$ of patients, in $38.46 \%$ - a cadaveric kidney transplantation (CKT). In all the patients, plasma creatinine level was within normative values or not exceeding them more than $25 \%$, on average, ranging from 94 to $130 \mu \mathrm{mol} / \mathrm{L}$ and its mean value was $114.50 \pm 3.85 \mu \mathrm{mol} / \mathrm{L}$.

The second study was based on the ultrasound examination results of the renal transplants in 26 patients with creatinine levels exceeding the standard values (group 2) during the period 2015-2016. The second group of recipients consisted of $14(53,84 \%)$ male and $12(46.16 \%)$ female, the mean age was $38.99 \pm 2.32$ years. LRKT was performed in 6 patients, and CKT in 20 patients. In all the patients plasma creatinine level was above the normal range, on average, ranging from 155 to $629 \mu \mathrm{mol} / \mathrm{L}$ and its mean value was $259.46 \pm 35.33 \mu \mathrm{mol} / \mathrm{L}$. The patients of both groups had comparable main clinical and demographic parameters. 
The ultrasound examination was performed with a Toshiba (Xario) device using a convex multi-frequency transducer at $3-5 \mathrm{MHz}$ and included the state assessment and topometry of kidney transplant, the state of perirenal space assessment, color Doppler and spectral Doppler. To assess the kidney transplant state, we determined the kidney contour, homogeneity and echogenicity of the parenchyma, the clarity of cortical-medullary differentiation, the renal pelvis system and ureter state. Length and front-rear sizes of kidney transplant were dimensioned by topometry. The parenchyma and cortical layer thickness was calculated as the average value of the three measurements in the middle segment of kidney transplant.

The renal arteries blood flow was measured at the renal artery trunk and the interlobar branches of the renal artery (IBRA) levels by the spectral Doppler ultrasound evaluating the linear velocity indices. In addition, "almost angle-independent" indicators of peripheral vascular resistance (resistivity) were used. The renal vessels vascular resistivity was calculated by processing the Doppler waveforms using standard formulas.

The Doppler spectral waveform shape was evaluated and the following parameters were determined: peak systolic velocity (PSV), end-diastolic velocity (EDV), resistance index (RI) and pulsatility index (PI) of the blood flow, systolic-diastolic ratio (SDR), acceleration time (AT), time-averaged maximum velocity (TAMX) both in the renal and interlobar arteries. The angle of insonation was in the range from $30^{\circ}$ to $60^{\circ}$. The average indicators of blood flow were analyzed throughout 3-6 cardiac cycles by Dopple spectrum. In addition, the linear blood flow velocity (LFV) in the renal vein was also evaluated.

Serum creatinine concentration was measured using the Jaffe color reaction (Popper method). All biochemical studies were performed at the Central Clinical and Express Biochemical Laboratories of the Zaporizhzhia Regional Clinical Hospital.

The data were fist examined for normality using the Kolmogorov-Smirnov test. Parametric and non-parametric methods of data analysis were used. The results were presented as mean and standard error of representativeness of the sample standard value. The study results were processed using the statistical package of the licensed program Statistica ${ }^{\circledR}$ for Windows 6.0 (StatSoft Inc., NAXXR712D833214FAN5), SPSS 17.0 and Microsoft Excel 2010. Separate statistical procedures and algorithms were implemented as specially written macros in the corresponding programs. Statistical significance was defined as $P<0.05$ for all types of differences.

\section{Results}

For the kidney transplant evaluation in patients with normal plasma creatinine levels (group 1), the following results were obtained by B-mode imaging and topometry: parenchyma thickness was $17.23 \pm 0.35 \mathrm{~mm}$, cortical substance $7.15 \pm 0.20 \mathrm{~mm}$, cortical-medullary differentiation were defined as clear in the vast majority - $92.31 \%$, fuzzy - in $7.69 \%$ of the examined patients, the echogenicity of kidney transplant parenchyma was isoechoic in all the patients (100\%). LFV in the renal vein averaged about $34.06 \pm 3.18(27.69-40.43)$ $\mathrm{cm} / \mathrm{s}$. For the renal transplants evaluation in patients with plasma creatinine levels exceeding standard values (with impaired depuration function, group 2), the following results were obtained by $\mathrm{B}$-mode imaging and topometry: parenchyma thickness was $17.35 \pm 0.45(16.45-18,25) \mathrm{mm}$, cortical substance $-7.8 \pm 0.28(7.25-8.35) \mathrm{mm}$. The cortical-medullary differentiation was defined as clear in the majority of the examined patients - in $73.01 \%$; the echogenicity of parenchyma was increased in $23.1 \%$ of patients. LFV in the renal vein averaged about $23.98 \pm 2.22(19.54-28.43) \mathrm{cm} / \mathrm{s}$.

The results of spectral Doppler indicators of renal graft hemodynamics (renal artery trunk) in patients without signs and with signs of renal graft dysfunction in the long-term period following KT are presented in Table 1.

As can be clearly seen from the presented data, the parameters of renal artery resistance and marked velocity gradient in patients with relatively normal serum creatinine levels (group 1) in the long-term period following $\mathrm{KT}$, despite the differences from the reference values, did not reach statistical significance, which was not the case for acceleration time dynamics and TAMX, as statistically significant differences were noted in the CKT recipients: $23.08 \%(P<0.05)$ and $13.5 \%(P<0.05)$, respectively.

According to the obtained results, in patients with efficient kidney transplant function after LRKT (group 1), the PSV in the renal artery was $32.89 \%$ higher than in those with renal dysfunction (group 2) after LRKT. After CKT, the differences between groups of patients with and without renal dysfunction (group 1 and 2) were $2.08 \%$, not being clinically significant. However, the greatest differences were revealed in such indicators as EDV in the renal artery and TAMX. EDV in the renal artery was $76.77 \%$ higher in patients with efficient renal function (group 1) after LRKT than in those with impaired kidney transplant function (group 2). The same indicator was $44.83 \%$ higher in patients with efficient kidney transplant function (group 1) compared to those with kidney transplant dysfunction (group 2) after CKT. Regarding such an indicator

Table 1. The Doppler spectrum parameters of the renal transplant blood flow in patients with efficient and impaired depuration function (renal artery trunk) in the long-term period following KT

\begin{tabular}{|c|c|c|c|c|}
\hline \multirow[t]{2}{*}{ Indicators, units } & \multicolumn{2}{|c|}{ Efficient function of depuration (group 1) } & \multicolumn{2}{|c|}{ Impaired function of depuration (group 2) } \\
\hline & $\begin{array}{l}\text { Living related kidney } \\
\text { transplants }(n=16) \\
M \pm m\end{array}$ & $\begin{array}{l}\text { Cadaveric kidney } \\
\text { transplants }(n=10) \\
M \pm m\end{array}$ & $\begin{array}{l}\text { Living related kidney } \\
\text { transplants }(\mathrm{n}=10) \\
\mathrm{M} \pm \mathrm{m}\end{array}$ & $\begin{array}{l}\text { Cadaveric kidney } \\
\text { transplants }(n=16) \\
M \pm m\end{array}$ \\
\hline Peak systolic velocity (PSV), renal artery trunk, $\mathrm{cm} / \mathrm{s}$ & $94.75 \pm 8.06$ & $79.5 \pm 5.04$ & $71.30 \pm 6.65^{\star}$ & $77.88 \pm 5.43^{*}$ \\
\hline End-diastolic velocity (EDV), renal artery trunk, $\mathrm{cm} / \mathrm{s}$ & $35.00 \pm 2.94$ & $31.95 \pm 1.97$ & $19.80 \pm 1.58^{*}$ & $22.06 \pm 1.77^{*}$ \\
\hline Systolic/diastolic ratio (SDR), relative units & $2.76 \pm 0.17$ & $2.51 \pm 0.10$ & $3.69 \pm 0.34^{*}$ & $3.60 \pm 0.12^{*}$ \\
\hline Pulsatility index (PI), renal artery trunk, relative units & $1.08 \pm 0.07$ & $1.0 \pm 0.05$ & $1.44 \pm 0.12^{*}$ & $1.44 \pm 0.04^{*}$ \\
\hline Resistance index (RI), renal artery trunk, relative units & $0.62 \pm 0.02$ & $0.6 \pm 0.02$ & $0.71 \pm 0.02^{*}$ & $0.72 \pm 0.01^{*}$ \\
\hline Acceleration time (AT), sec & $0.13 \pm 0.01$ & $0.16 \pm 0.01$ & $0.14 \pm 0.01^{*}$ & $0.12 \pm 0.01^{*}$ \\
\hline TAMX, cm / sec & $54.87 \pm 4.63$ & $47.46 \pm 2.76^{*}$ & $35.48 \pm 2.38^{*}$ & $39.02 \pm 2.77^{*}$ \\
\hline
\end{tabular}

*: the statistical significance of differences in comparison to the group with efficient depuration function is less than 0.05 
Table 2. The Doppler spectrum parameters of the renal transplant blood flow in patients with efficient and impaired depuration function (interlobar arteries) in the long-term period following KT

\begin{tabular}{|c|c|c|c|c|}
\hline \multirow[t]{2}{*}{ Indicators, units } & \multicolumn{2}{|c|}{ Efficient function of depuration (group 1) } & \multicolumn{2}{|c|}{ Impaired function of depuration (group 2) } \\
\hline & $\begin{array}{l}\text { Living related kidney } \\
\text { transplants } \\
(\mathrm{n}=16), \mathrm{M} \pm \mathrm{m}\end{array}$ & $\begin{array}{l}\text { Cadaveric kidney } \\
\text { transplants } \\
(\mathrm{n}=10), \mathrm{M} \pm \mathrm{m}\end{array}$ & $\begin{array}{l}\text { Living related kidney } \\
\text { transplants }(\mathrm{n}=10) \\
\mathrm{M} \pm \mathrm{m}\end{array}$ & $\begin{array}{l}\text { Cadaveric kidney } \\
\text { transplants } \\
(\mathrm{n}=16), \mathrm{M} \pm \mathrm{m}\end{array}$ \\
\hline \multicolumn{5}{|l|}{ Upper segment } \\
\hline Peak systolic velocity (PSV), interlobar branches of the renal arteries $\mathrm{cm} / \mathrm{s}$ & $32.13 \pm 2.23$ & $30.1 \pm 1.04$ & $24.1 \pm 1.52^{*}$ & $20.94 \pm 1.32^{*}$ \\
\hline End-diastolic velocity (EDV), interlobar branches of the renal arteries, $\mathrm{cm} / \mathrm{s}$ & $13.38 \pm 1.03$ & $12.9 \pm 0.64$ & $8.7 \pm 0.78^{*}$ & $7.69 \pm 0.41^{*}$ \\
\hline Systolic/diastolic ratio (SDR), relative units & $2.44 \pm 0.08$ & $2.43 \pm 0.11$ & $2.93 \pm 0.33^{*}$ & $2.73 \pm 0.11^{*}$ \\
\hline Pulsatility index (PI), interlobar branches of the renal arteries, relative units & $0.94 \pm 0.03$ & $0.92 \pm 0.04$ & $1.19 \pm 0.11^{*}$ & $1.09 \pm 0.04^{*}$ \\
\hline Resistance index (RI), interlobar branches of the renal arteries, relative units & $0.58 \pm 0.01$ & $0.58 \pm 0.02$ & $0.63 \pm 0.03$ & $0.62 \pm 0.01$ \\
\hline Acceleration time (AT), s & $0.14 \pm 0.01$ & $0.13 \pm 0.01$ & $0.15 \pm 0.01$ & $0.14 \pm 0.01$ \\
\hline TAMX, cm/s & $19.99 \pm 1.38$ & $19.05 \pm 0.63$ & $13.18 \pm 0.88^{*}$ & $11.99 \pm 0.67^{*}$ \\
\hline \multicolumn{5}{|l|}{ Middle segment } \\
\hline Peak systolic velocity (PSV), interlobar branches of the renal arteries $\mathrm{cm} / \mathrm{s}$ & $33.0 \pm 2.8$ & $30.9 \pm 1.82$ & $25.7 \pm 1.78^{*}$ & $24.81 \pm 1.78^{*}$ \\
\hline End-diastolic velocity (EDV), interlobar branches of the renal arteries, $\mathrm{cm} / \mathrm{s}$ & $12.38 \pm 0.96$ & $13.0 \pm 0.82$ & $8.3 \pm 0.79^{*}$ & $8.01 \pm 0.7^{\star}$ \\
\hline Systolic/diastolic ratio (SDR), relative units & $2.7 \pm 0.1$ & $2.41 \pm 0.12$ & $3.42 \pm 0.4^{*}$ & $3.21 \pm 0.16^{*}$ \\
\hline Pulsatility index (PI), interlobar branches of the renal arteries, relative units & $1.02 \pm 0.04$ & $0.93 \pm 0.04^{*}$ & $1.29 \pm 0.12^{*}$ & $1.26 \pm 0.06^{*}$ \\
\hline Resistance index (RI), interlobar branches of the renal arteries, relative units & $0.62 \pm 0.01$ & $0.58 \pm 0.02^{*}$ & $0.68 \pm 0.03$ & $0.68 \pm 0.02$ \\
\hline Acceleration time (AT), s & $0.13 \pm 0.01$ & $0.14 \pm 0.01$ & $0.14 \pm 0.01$ & $0.13 \pm 0.01$ \\
\hline TAMX, cm/s & $19.63 \pm 1.47$ & $19.4 \pm 1.15$ & $14.05 \pm 1.06^{*}$ & $13.41 \pm 1.02^{*}$ \\
\hline \multicolumn{5}{|l|}{ Lower segment } \\
\hline Peak systolic velocity (PSV), interlobar branches of the renal arteries $\mathrm{cm} / \mathrm{s}$ & $32.06 \pm 1.73$ & $31.3 \pm 1.24$ & $20.4 \pm 1.23^{*}$ & $21.25 \pm 1.55$ \\
\hline End-diastolic velocity (EDV), interlobar branches of the renal arteries, $\mathrm{cm} / \mathrm{s}$ & $13.31 \pm 0.78$ & $12.9 \pm 0.46$ & $7.6 \pm 0.6^{*}$ & $6.78 \pm 0.46^{*}$ \\
\hline Systolic/diastolic ratio (SDR), relative units & $2.43 \pm 0.09$ & $2.42 \pm 0.12$ & $2.8 \pm 0.2$ & $3.26 \pm 0.27^{*}$ \\
\hline Pulsatility index (PI), interlobar branches of the renal arteries, relative units & $0.94 \pm 0.04$ & $0.93 \pm 0.05$ & $1.14 \pm 0.08^{*}$ & $1.26 \pm 0.07^{*}$ \\
\hline Resistance index (RI), interlobar branches of the renal arteries, relative units & $0.58 \pm 0.01$ & $0.58 \pm 0.02$ & $0.63 \pm 0.02$ & $0.67 \pm 0.02^{*}$ \\
\hline Acceleration time (AT), s & $0.13 \pm 0.01$ & $0.16 \pm 0.01$ & $0.14 \pm 0.01$ & $0.14 \pm 0.01$ \\
\hline TAMX, cm/s & $19.89 \pm 0.95$ & $19.38 \pm 0.65$ & $11.48 \pm 0.79^{*}$ & $10.78 \pm 0.97^{*}$ \\
\hline
\end{tabular}

*: the statistical significance of differences in comparison to the group with efficient depuration function is less than 0.05 .

of renal hemodynamics as TAMX, the difference was $54.65 \%$ between patients with efficient renal function (group 1) and patients with kidney transplant dysfunction (group 2) after LRKT. The difference related to TAMX was determined at the level of $21.63 \%$ between the patients of CKT group with efficient and impaired renal function (group 1 and 2), which has significant clinical and prognostic significance.

An assessment of spectral Doppler parameters of renal transplant hemodynamics (interlobar arteries) in patients without signs and with signs of renal transplant dysfunction in the long-term period following KT are presented in Table 2.

In the upper segment, the EDV in the interlobar branches of the renal arteries in the LRKT group with efficient renal function (group 1) exceeded that in the LRKT group with impaired renal function by $53.79 \%$, and related to the group of patients after CKT the difference was $67.75 \%$, also in favor of patients with efficient depurative function. TAMX of interlobar branches of the renal arteries of the upper segment in the LRKT group with efficient function (group 1) exceeded the same indicator in the group with impaired function (group 2) by $51.67 \%$ and in the group after CKT - by $58.88 \%$.

The difference in EDV values in the interlobar branches of the renal arteries of the middle segment was verified at the level of $49.16 \%$ after LRKT and $62.30 \%$ after CKT, with higher indicators in patients of the group with the efficient depuration function (group 1). The TAMX index of interlobar branches of the renal arteries of the middle segment differed between groups with efficient and impaired renal function (group 1 and 2) after LRKT by $39.72 \%$ in favor of the group 1 , and after CKT - by $44.67 \%$ also in favor of the group 1 without kidney transplant dysfunction.
EDV in the interlobar branches of the renal arteries in the lower segment with renal dysfunction (group 2) after LRKT was $75.13 \%$ less compared to the group with normal renal function (group 1), and in the case of CKT the difference was $90.27 \%$ also in favor of kidney transplant with efficient function (group 1). SDR was higher in the groups with impaired depurative function (group 2): by $13.21 \%$ after LRKT and by $25.77 \%$ after CKT. The TAMX in the LRKT group with normal renal function (group 1) was $73.26 \%$ higher compared to the group with renal dysfunction (group 2), and after CKT was $79.78 \%$ higher also in favor of the group with normal depuration function of kidney transplant (group 1). That is, in the lower segment interlobar branches of the renal arteries, differences in indicators for groups with different renal function were more significant.

\section{Discussion}

Summing up the data obtained, it can be concluded that TAMX is not only an important parameter and a key marker of dysfunction at the initial stage of renal failure development, but it also adequately reflects the transplanted kidney functional status in recipients without transplant dysfunction.

Clinical manifestations of rejection are less pronounced and, as a rule, become evident only due to an increase in serum creatinine level or even occur subclinically. In recent years, studies have shown that rejection is the main cause of transplanted kidney failure in the long-term period following $\mathrm{KT}$, and late rejection occurs with the humoral immunity activation in most cases. 
Activation of the humoral immunity in the late rejection episodes development more determines its resistance to therapy and poor prognosis regardless of the morphological variant of the latter. Traditionally, acute and chronic humoral rejection are distinguished; however, in essence, these variants of rejection are stages of the same process, that begins with anti-donor antibodies production which form complexes with antigens on the surface of endothelium, that leads to the classical pathway of complement system activation resulting in inflammation development (acute rejection) and further vascular repair in the smallest blood vessels (chronic rejection) [9].

Despite the development of new, more powerful immunosuppressive agents, it has not yet been possible to completely overcome the problem of renal transplant rejection. At the same time, late rejection episodes, which despite the treatment are the most serious for prognosis, are manifested in further progression of kidney transplant dysfunction in most cases.

For a long time, the nature of such differences in the rejection course depending on the time of occurrence remained unclear, and only in recent years, it was possible to prove that humoral immunity activation plays an important role in the development of late rejection episodes. According to the data from the DeKAF study, more than $50 \%$ of patients with late dysfunction showed signs of acute or chronic kidney transplant rejection, and $57 \%$ of these patients showed signs of the humoral immunity activation [10].

Today, clinical diagnosis of graft rejection is based on histological examination of kidney transplant biopsies. Since a biopsy is usually performed only in increased creatinine levels, the beginning of rejection treatment is delayed for several days or even weeks. Such a delay contributes to tissue damage reducing graft survival. In addition, a biopsy is an invasive procedure, which cannot be performed as often as necessary for careful monitoring, so it is not an ideal method for the diagnosis of rejection.

It is important to note that the Doppler evaluation of transplant vessels to detect complications of kidney transplantation and the specifity of kidney transplant pathology has turned out to be a promising method of examination. Color mapping and pulsed dopplerography are considered as the most accurate in demonstrating a kidney transplant state and are the gold standard for monitoring the kidney transplant state and hemodynamic changes both in the early and long-term postoperative periods.

\section{Conclusions}

1. We conducted a comparative analysis of complex ultrasound indicators (grayscale with color and spectral Doppler ultrasonography) of blood flow that did not reveal significant differences between the patients with efficient depuration function after LRKT and CKT in the late postoperative period.

2. In patients after LRKT and CKT with impaired depurative function, lower TAMX values were recorded in comparison to patients without renal dysfunction, which can be a reliable diagnostic criterion and an important prognostic predictor for renal transplant dysfunction development.

3. The obtained data reliably indicate that if TAMX of interlobar arteries less than $15 \mathrm{~cm} / \mathrm{s}$, the probability to re- veal the clinical signs of renal allograft dysfunction is more than $90 \%$, regardless of the renal segment evaluation in recipients in the long-term period after KT.

Prospects for further research. This study would provide a perspective basis for proposed Doppler sonographic parameters using as possible criteria for impaired graft perfusion. These data will allow for a comparative analysis of Doppler indices in recipients with graft dysfunction, to define ultrasound criteria for kidney transplant dysfunction, and thereby to improve diagnosis and prolong graft survival.

Conflicts of interest: author has no conflict of interest to declare. Конфлікт інтересів: відсутній.

Надійшка Ао редакції / Received: 12.10.2018

Після Аоопрацювання / Revised: 18.10.2018

Прийнято Ао Аруку / Accepted: 30.10.2018

Information about author:

Yakymenko V. V., MD, Assistant of the Department of Radiation Diagnosis, SI "Zaporizhzhia Medical Academy of Postgraduate Education of the Ministry of Health of Ukraine".

\section{Відомості про автора:}

Якименко В. В., асистент каф. променевої Аіагностики, АЗ «Запорізька меАична академія післядипломної освіти М03 України".

Сведения об авторе:

Якименко В. В., ассистент каф. пучевой диагностики, ГУ «Запорожская медицинская академия послеАипломного образования МЗ Украины».

\section{References}

[1] Delmonico, F. L., Gunderson, S., Iyer, K. R., Danovitch, G. M., Pruett, T. L. Reyes, J. D., \& Ascher, N. L. (2018). Deceased Donor Organ Transplantation Performed in the United States for Non-Citizens and Non-Residents. Transplantation, 102(7), 1124-1131. doi: 10.1097/TP.0000000000002086

[2] Molina-Ortega, A., Martín-Gandul, C., Mena-Romo, J. D., Rodríguez-Hernández, M. J., Suñer, M., Bernal, C., et al. (2018). Impact of Pretransplant CMV-Specific T-cell Immune Response in the Control of CMV Infection after Solid Organ Transplantation: a prospective cohort study. ClinMicrobiol Infect, pii: S1198-743X(18)30657-8. doi: 10.1016/i.cmi.2018.09.019

[3] Nishimura, H., Yamada, Y., Hisano, S., Mitsuke, A., Tatarano, S., Gotanda, T., et al. (2018). Long-term desensitization for ABO-incompatible living related kidney transplantation recipients with high refractory and rebound anti-blood type antibody: case report. BMC Nephrol, 19(1), 254 doi: 10.1186/s12882-018-1053-8

[4] Ravindranath, M. H., Jucaud, V., Banuelos, N., Everly, M. J., Cai, J., Nguyen, A., \& Terasaki, P. I. (2017). Nature and Clonality of the Fluoresceinated Secondary Antibody in Luminex Multiplex Bead Assays Are Critical Factors for Reliable Monitoring of Serum HLAAntibody Levels in Patients for Donor Organ Selection, Desensitization Therapy, and Assessment of the Risk for Graft Loss. J Immunol, 198(11), 4524-4538. doi: 10.4049/jimmunol. 1700050

[5] Solid, C. A., Peter, S. A., Natwick, T., Guo, H., Collins, A. J., \& Arduino, J. M. (2017). Impact of Renal Disease on Patients with Hepatitis C: A Retrospective Analysis of Disease Burden, Clinical Outcomes, and Health Care Utilization and Cost. Nephron, 136(2), 54-61. doi: 10.1159/000454684

[6] Lees, J. S., McQuarrie, E. P., \& Mackinnon, B. (2018). Renal biopsy: it is time for pragmatism and consensus. Clin Kidney J, 11(5), 605-609. doi: 10.1093/ckj/sfy075

[7] Incerti, D., Summers, N., Ton, T. G. N., Boscoe, A., Chandraker, A., \& Stevens, W. (2018). The Lifetime Health Burden of Delayed Graft Function in Kidney Transplant Recipients in the United States. MDM Policy Pract, 3(1), 2381. doi: 10.1177/2381468318781811

[8] Apel, H., Putz, J., Fornara, P., Friedersdorff, F., Dreikorn, K., \& Stöckle, M. (2017). Report of the 24th annual conference of the Working Group Kidney Transplantation of the German Society of Urology in Erlangen. Urologe A, 56(9), 1182-1184. doi: 10.1007/s00120-017-0452-y

[9] Lim, E., Kim, Y., Jeong, J. C., Park, I., Kim, H., Lee, S. H., et al. (2017). Clinical analysis of single filtration plasmapheresis using continuous renal replacement therapy machines in kidney transplantation. Kidney Res ClinPract, 36(2), 192-199. doi: 10.23876/j.krcp.2017.36.2.192

[10] Kezić, A., Stajic, N., \& Thaiss, F. (2017). Innate Immune Response in Kidney Ischemia/Reperfusion Injury: Potential Target for Therapy. J Immunol Res, 2017, 6305439. doi: 10.1155/2017/6305439 